\title{
IMPULZY PRE PRÍŤAŽLIVÉ PÓLY STRETNUTIA
}

\author{
IMPULSES FOR ATTRACTIVE MEETING POLES
}

doc. Ing. arch. Silvia Bašová, Ph.D.

\begin{abstract}
ABSTRAKT
Podnety pre stretnutia $\mathrm{V}$ priestore mesta sú vel'mi dôležité faktory v procese navrhovania verejných priestranstiev. Sociálne impulzy pre vytváranie verejných priestranstiev podl’a sociálnej štruktúry (spoločných priestorov pre deti a mládež, miest pre seniorov a miest pre každého) musia byt’ prijaté a integrované od designérov, architektov aj urbanistov. Význam kultúrnych impulzov je dôležitý pre interaktivitu kultúrnych aktivít a lokálnej participácie obyvatel’ov voblasti umenia. Návštevníci vyhl'adávajú možnost' atraktívneho zažívania priestoru, vitálne funkcie v parteri, priamu účast' na spoločenskom živote v exteriéri, stretnutia, oddych, relax, účast' na scéne deja na námestiach, tranzit námestím. Je dôležité poskytnút komplexné využitie námestí a parkov ako multifunkčnú destináciu v súčasných mestách.
\end{abstract}

Kl'účové slová: Impulzy pre atraktívne póly stretnutia, sociálne impulzy, kultúrne impulzy, atraktívne zažívanie priestoru

\section{ABSTRACT}

Impulses for meeting in the city are very important factors in the design process of public spaces. Social impulses for the creation of public spaces according to social structure (public areas for children and the young, places for seniors, and places for everyone) need to be accepted and integrated by designers, architects and urban designers. Visitors search for an attractive opportunity to experience vitality in parterre, direct participation in the social life and meetings outside, rest, to relax, to participate in the street sceneries or transit Square. The importance of cultural impulses plays a basic role in interactivity of cultural activities and local participation in the arts. It is important to provide complex using squares and parks as multifunctional destination in contemporary towns.

Keywords: Impulses for attractive meeting poles, social impulses, cultural impulses, attractive use of space

\section{1 ÚVOD}

Významné póly stretnutia - verejné priestory sa stávajú stále viac prítažlivým dejiskom spoločenského života. Tieto historicky overené priestory: námestia, významné mestské ulice, pasáže, nádvoria, nábrežia nestrácajú ani dnes na svojej aktuálnosti. Ich atraktívnost’ je výsledkom mnohých faktorov. Na verejný priestor sa môžeme pozerat' z viacerých uhlov pohl'adu: z dejinného vývoja, z aktuálnych potrieb súčasnej spoločnosti, zhl'adiska urbánnej a architektonickej koncepcie, z hladiska reprezentácie mesta.... Nie je to len urbanistická problematika. Komplementárne názory architektov, designérov, sociológov, filozofov, urbanistov a d'alších profesií na tieto priestory sú potrebné pre spojenie viacerých odborných horizontov do jedného celku. Pohl'ady na kvalitu verejného priestoru $\mathrm{v}$ súčasnosti významne rezonujú aj $\mathrm{v}$ participatívnom modeli dotvárania miest mesta. Zdanlivo čiastkové dojmy, zážitky, vnemy, percepčné stopy a atmosféra prostredia, vnímaná jej účastníkmi, sú významnými zdrojmi poznania prostredia a jeho potenciálov pre dotváranie celistvých urbánnych koncepcií. Participatívne plánovanie významne prispieva k procesu dotvárania 
verejných priestorov práve účast'ou jej užívatel’ov, hlavných aktérov deja priestorov, na premenách a víziách exteriéru mesta.
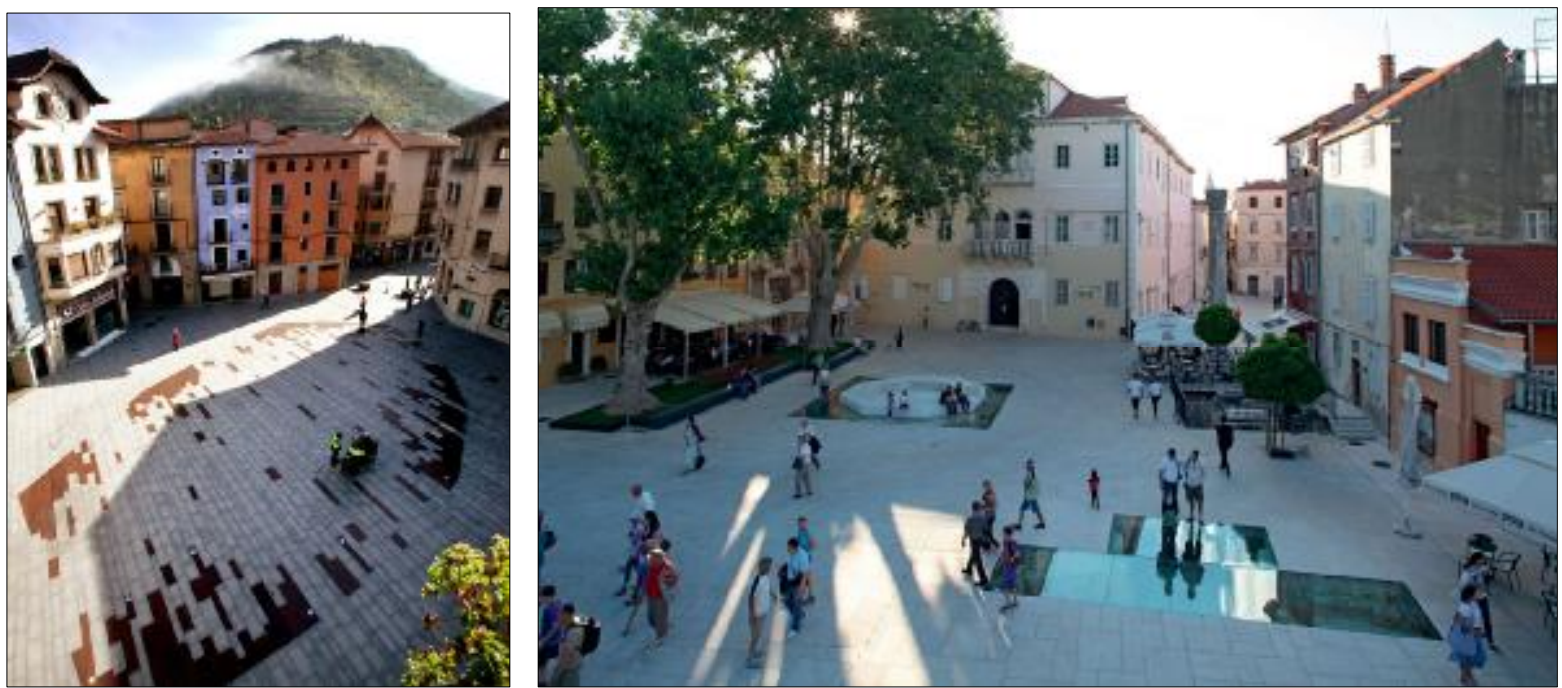

Obr. 1 nový design a dotvorenie historického námestia v Ripoll, Plaça Sant Eudald, Španielsko www.sk.pinterest.com/pin/327848047853384784/

Obr. 2 nový design a dotvorenie historického námestia v Zadare, Námestie Petra Zoranića, Chorvátsko www.wikipedia.org/wiki/European_Capital_of_Culture

\section{STRETNUTIE V MESTE}

\subsection{Impulzy pre stretnutie v priestore mesta}

Urbánny význam námestia - ako centrálneho verejného priestoru mesta, ktorý je spravidla lokalizovaný v jeho prevádzkovom a kompozičnom t’ažisku, je u väčšiny námestí jasne vymedzený a definovaný. Tektonické vymedzenie a kompozičné navádzanie k námestiu napomáha k orientácií a k vnímaniu jeho ohraničenia. Jasnost' konceptu dáva účastníkom istotu $\mathrm{k}$ pohybu i pobytu. Nie všetky priestory námestí sú však takto jasne čitatel’né. Práve tie jasne vymedzené sú podmienkou urbánnej kvality a tým aj výbornou „scénou pre stretnutie“. K stratám tektonickej hrany námestia došlo predovšetkým v období moderny a po nej. Postmoderný urbanizmus vel'mi výstižne zareagoval na stratu klasickej priestorovej osnovy a snažil sa o obnovené uchopenie celku s dôrazom na jeho centrálne uzly - námestia. J. B. Jacobsová, R. Ch. Venturi, R. a L. Krier, R. Bofill upozorňujú v druhej polovici 20. st. na aktuálnost' návratu ku klasickému chápaniu priestoru námestia a odkazujú na teórie C. Sitteho. [9] Námestie sa po epoche moderny a postmoderny opät' stabilizovalo a ideovo sa vrátilo k svojmu pôvodnému zmyslu.

„...každé pravé mesto, a teda aj malé mestské mesto je kultúrna forma, a nie technicko - sociologický stereotyp, takže ho nemožno vytvorit' na objednávku, vzniká podl'a akýchsi zložitých, významných, skrytých a relatívne volných pravidiel hry, ku ktorým moderný urbanizmus, posadnutý mániou exaktného plánovania, nemôže ešte vždy preniknút. “ [4]

Na priestorovej osnove, ktorú mestá zdedili, sa dnes urbanisti snažia o renesanciu podstaty námestia s premenami mestského interiéru. Vytvárajú sa aj nové uzlové priestory, často sú však oslabené hlavne na kompozičnej kvalite. V hre sú viac otázky kvality ako kvantity. Taktiež prímestské sídla trpia nedostatkom verejných priestorov, realizovaných $\mathrm{v}$ potrebnej kvalite. To spôsobuje izoláciu obyvatel'stva $\mathrm{v}$ obytných štruktúrach a potláča priprodzenú sociabilitu a komunikáciu miestnych lokalít. [12] Súdobé námestie - ako výnimočný priestorový celok, je tak opät’ a znova - ako v dejinách stavby miest, tektonicky vymedzeným centrálnym miestom pre stretávanie l'udí a pre realizáciu spoločenských aktivít. Jeho súčasné premeny prebiehajú skôr v zmysle dokomponovania ako hl'adania nových foriem. Opätovný dôraz na merítko peších a dôležitost' verejných priestorov pripomína v svojich teoretických dielach dánsky urbanista a teoretik Jan Gehl. Do popredia sa dnes dostávajú otázky záujmu návštevníkov o živé a atraktívne priestory, impulzy pre stretnutia. Otázky vitality 
a humánnych parametrov sa týkajú nielen dotvárania priestorov, ale aj správcov mesta, ktorí očakávajú rastúcu urbánnu prosperitu a návštevnost'. Dôležitost' prít’ažlivosti priestoru námestia a t'ažiskových verejných priestorov nie je samozrejmost'ou, ktorú by sme očakávali. Vitalita súvisí aj s ponukou skladby a funkcie priestoru pre rozličné vekové a záujmové skupiny, resp. integráciu týchto skupín.

\section{Sociálne impulzy pre tvorbu verejných priestorov:}

- Miesto pre deti a mladých

zohl'adnenie multifunkčných plôch pre pohybové aktivity detí a mladých rôznych vekových kategórií, dynamika dotvorenia designu týchto plôch, možnost' tvorivých prejavov: sútaží, umeleckých scén, workshopov;
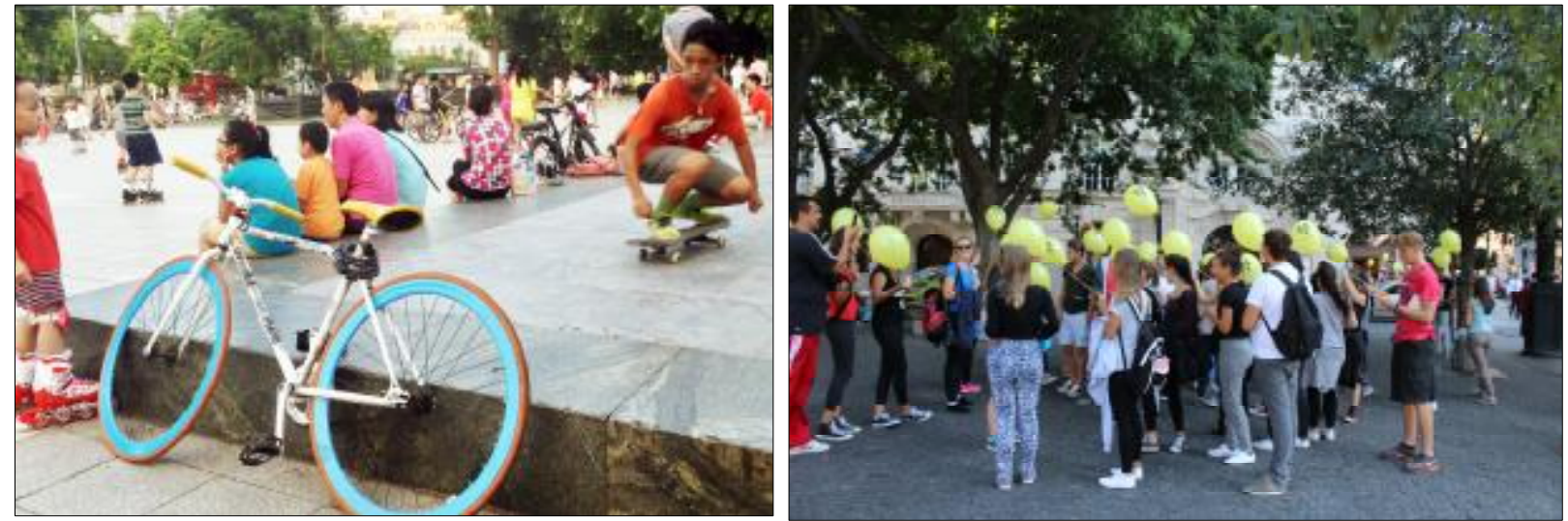

Obr. 3 stretnutie mladých cyklistov a korčuliarov v Hanoji, www.hanoiyouthpublicspace.com/gallery Obr. 4 stretnutie mladých v parku pred Redutou v Bratislave, foto Silvia Bašová

\section{- Miesto pre seniorov}

zohl’adnenie miest na stretnutie, posedenie, ponuka cukrární, kaviarničiek, gastro - obslužných prevádzok, dôraz na pohodlný design, miesta slnečné i v tieni, výhl’ady, kontakt s ostatnými skupinami, ponuka kultúrnych podujatí vo vol'nom priestranstve, bezbariérovost';

- Miesto pre všetkých

integrácia funkčnej ponuky verejného priestoru pre všetky vekové kategórie a záujmové skupiny;

\section{Kultúrne impulzy}

Kultúrne impulzy smerujú k interaktivite vo verejnom priestore, s dôrazom na participáciu na umení, umeleckých aktivitách a podujatiach. Mnohé námestia, ktoré stratili v slede času formu, funkciu i pôvodnú silu, sú opustené, degradované a nekultúrne. Úloha revitalizácie týchto priestorov nie je len $\mathrm{v}$ rukách profesionálov. Konečne sú v hre dotvárania mesta aj jeho obyvatelia a občianske zoskupenia. Dialóg s vitálnou zložkou procesu - s jeho obyvatel'mi je nutnou súčast'ou dobrého konceptu. Teamovou prácou môže dôjst' k tvorivej premene a zhodnoteniu miesta. K tvorbe tak pribúda komunikácia, empatia. Oživená umelecká idea môže byt' účinná pre vytvorenie kvalitného návrhu priestoru, ku ktorému si ludia vytvoria vzt'ah, stanú sa jeho aktérmi. Vtedy začne rást' oblúbenost' miesta spolu s vitalitou. Vitalita verejných priestorov je potom akousi výslednou hodnotou, známkou, ktorú užívatelia dávajú danému miestu.

Motívy stretnutia l’udí na námestí sú cielené alebo spontánne situácie, ktoré kulminujú v určitých časových sekvenciách rytmu mesta. Návštevníci vyhl’adávajú:

*možnost' zotrvania v atraktívnom priestore, funkcie v parteri

*priamu účast' na spoločenskom živote v exteriéri

*plánované i neplánované, osobné i skupinové stretnutia

*oddych, relax, zažívanie scény deja námestia

*tranzit námestím 


\subsection{Významné podnety $\mathrm{k}$ zastaveniu peších}

V prostredí mesta, a predovšetkým v prostredí rýchleho tempa vel'komesta, je verejný priestor cielom urbánneho pohybu, tiež priestorovou výzvou $\mathrm{k}$ zastaveniu a k zažívaniu priestoru. Tento priestor je svojím určením nadčasový, je to oporný bod, miesto a mesto v meste. Je skúsenost'ou potvrdené, že tam, kde už l’udia sú, pribudnú d'alší a d’alší. Tiež je známa skúsenost', že prázdne miesta a námestia sa ešte viac vyprázdňujú. Skúmanie naplnenia a vyprázdnenia priestoru mesta, resp. miesta v meste je významným systémom psychologických a sociologických prieskumov, indikujúcich ideu urbánnej premeny. Sociologické prieskumy, vychádzajúce z chicagskej školy „human ecology“, sa viažu na zakomponovanú zložku priestoru a času. Urbánne zázemie námestia je tým základným priestorovým archetypom, v ktorom môžeme pozorovat' a overovat' dej účastníkov. Sociologické prieskumy tu v určitom vymedzenom priestore sledujú priebeh sociálnych procesov a javov, analyzujú podoby zmien sociálnych subjektov, ktoré daný priestor vyplňujú. Priestor $-\mathrm{v}$ tomto prípade mesta - je určitou scénou, územne štruktúrovanou, v ktorej spomínané sociálne procesy a javy vystupujú a dávajú mu určitú sociálnu charakteristiku. [5] Táto tektonicky vymedzená scéna je pevným oporným bodom, ku ktorému urbánna štruktúra graduje a ku ktorému sa mesto hierarchicky zahust’uje. Námestie je priestor stretnutia, priestor prezentačných aktivít, ale aj miesto oddychu a zažívania príjemnej atmosféry. Je to akási multifunkčná platforma adaptabilná podl’a mestských vízií a psychologických a sociálnych potrieb návštevníkov. Významná je identifikácia človeka $\mathrm{s}$ mestskom prostredí, jeho pocit spolupatričnosti k miestu a jeho sloboda vybrat' si spôsob, ako trávit’ vol’ný čas v meste. [2]
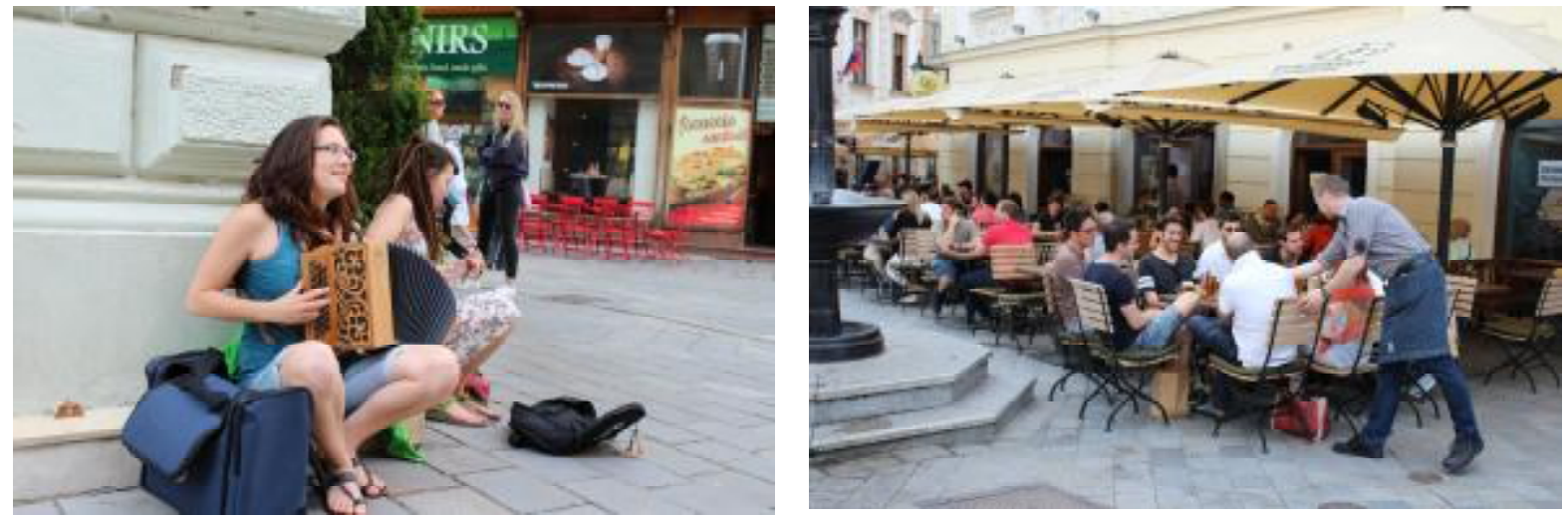

Obr. 5 zážitková rovina v horizonte peších, korzo Bratislava, foto autora (Bašová, Silvia)

Obr. 6 stretnutia a priatel'ská atmosféra na pešej zóne v Bratislave, foto autora (Bašová, Silvia)

„Kvalitný verejný priestor posilnujue sociálne prostredie. Vytvára siet' vzt'ahov a kontaktov známych ale aj anonymných návštevníkov, pasantov, domácich či turistov. Je to akoby pozvanie k prežívaniu iných chvíl' ako tých povinných, čisto utilitárnych, každodenných. Obyvatelia potrebujú urbanizmus, ktorý sa orientuje na človeka. Nielen vyspelá technická a komerčná infraštruktúra posúva urbanitu k vitalite, ale mestá a miesta urbanizované s úctou k l’ud'om v danom priestore. " [7]

\subsection{Vitalita a kvalita verejných priestorov}

Impulzy $\mathrm{k}$ zastaveniu v priestore mesta akcelerujú mestotvorný charakter daných miest. Vitalita verejných priestorov je priamo odvodená od sústavy aktivít, atraktivít a miest zastavenia. Súčasné mesto je pod vel'kým tlakom hospodárskeho prosperovania na úkor sociálneho, kultúrneho a duchovného prosperovania. Nárast vitality prostredia a miera spokojnosti obyvatel'ov, a teda aj kvality mesta by sa mala sústredit' viac na vyváženost' urbánnych parametrov ako na expanziu hustoty a mestskej dynamiky. [1] 


\subsection{Vitalita silných miest}

Na Slovensku sú to Bratislava a Košice, dve najsilnejšie mestá, ktoré znamenajú potenciál aj pre návštevnost' významných verejných priestorov. Prítažlivost' týchto dvoch miest je príznačná pre permanentný sumár výhod, ktoré sú nad’alej magnetmi prílivu obyvatel'ov. Tendencie sústredenosti obyvatel'ov do hlavných a silných miest sú globálne. Situácia nárastu obyvatel'ov je samozrejme kvantitatívne premenlivá, súvisiaca aj s procesom suburbanizačných vĺn. Okrem rezidenčnej rozpínavosti miest sa pridružila aj komerčná suburbanizácia, modifikujúca prímestskú krajinu. [6] Výhody i nevýhody týchto procesov sa intenzívne podiel'ajú na urbánnych premenách centrálnych i periférnych verejných priestorov.

Okrem expanzie vel'komiest dochádza v posledných rokoch $\mathrm{v}$ niektorých mestách aj $\mathrm{k}$ protichodnému javu, k „urban shrinking“ - k úbytku a zmenšovaniu niektorých mestských častí, k stratám živosti verejných priestorov, k úbytku počtu obyvatel’ov a tiež $\mathrm{k}$ stratám urbánnej stability. Zmenšovanie miest sa na Slovensku dotklo po roku 1996 až 11 stredne vel'kých miest. S týmto faktom klesá nielen celkový počet obyvatel'ov, ale aj verejné priestory zažívajú prázdnotu. Úbytok a zmenšovanie malých miest a vízia zvyšovanie priemerného veku obyvatel'stva vo vel'kých mestách sú reálne parametre, s ktorými je nutné počítat'. [3] Urbanisti musia akceptovat' dané socio - demografické výsledky aj pri modelovaní miest stretnutia. Ide však aj o spätné väzby. Kvalita dotvorenia miest stretnutia, ich redesign a ponúkané aktivity spätne vplývajú na návštevnost', rozvoj sociálnych interakcií a na sociálnu klímu obyvatel’ov a návštevníkov. Luudia modelujú mesto ale aj mesto modeluje l’udí.

\section{ZÁVER}

Vyššie uvedené skutočnosti, sociálne transformácie rýchleho rastu vel'kých a stredných miest i nečakaného zmenšovania iných miest postavili pred nás otázky dôrazu na mestské impulzy. Tieto súvisia nielen s otázkami a parametrami ekonomického, sociálneho a plánovacieho charakteru. Súvisia s celkovou kultúrnou úrovňou miest, s kultúrnymi výzvami a premenami.

Preto vznikli iniciatívy typu „Art and the City“ [11] a tiež vyše tridsat’ ročná skúsenost’ s Európskymi mestami kultúry:

\begin{tabular}{|c|c|c|c|}
\hline \multirow[t]{2}{*}{2015} & Mons & Belgium & Mons 2015 \\
\hline & Plzeň & Czech Republic & Plzeň 2015 \\
\hline \multirow[t]{2}{*}{2016} & San Sebastián & Spain & San Sebastián 2016 \\
\hline & Wrocław & Poland & Wrocław 2016 \\
\hline \multirow[t]{2}{*}{2017} & Aarhus & Denmark & Aarhus 2017 \\
\hline & Pafos & Cyprus & Pafos 2017 \\
\hline \multirow[t]{2}{*}{2018} & Leeuwarden & Netherlands & Leeuwarden-Fryslân 2018 \\
\hline & Valletta & Malta & Valletta 2018 \\
\hline
\end{tabular}

Tab. 1 Nominácie a výsledky vybraných európskych miest kultúry na roky 2015-2018, podl’a: [13]

Týmto procesom sa dostávame tiež k významu miest stretnutia a k ich kultúrnemu poslaniu. Zdravá sút’ǎivost' miest, možnost' prezentácie kultúrnych pólov a reprezentácie kultúrnych kvalít vedie mestá k premenám i spolupráci. Na kultúrne zázemie mesta a námestia nadväzujú aj vznikajúce kreatívne štvrte a klastre. [10] Kultúrne mesto sa takto stáva priestorovou integráciou kultúrnych pólov a kompaktnou štruktúrou, vrcholiacou v jeho ohniskách.

„Kultúrny zmysel mesta spočíva v tom, že mesto svoju vonkajšou podobou $i$ vnútornou organizáciou všetkých procesov sprítomñuje a formuje systém a významovú štruktúru života jeho obyvatelov a celkovú súvislost' bytia, v ktorej sa človek svojim každodenným životom ocitá. “ [8]

Nové trendy impulzov pre prít’ažlivé miesta mesta by mali spájat' viaceré atraktívne mestské ohniská navzájom. Tiež treba pamätat' na sociálne požiadavky rôznych skupín obyvatel'stva a tiež na 
multifunkčné priestory kultúrneho charakteru. Vitálne miesta formujú vitálne komunity, a vitálne komunity podnecujú k zmenám pre aktuálne využitie verejných priestorov mesta.

\section{Použitá literatúra}

[1] Bašová, S.: Urbánna vitalita. In: ALFA, 2/2014, ISSN 1135-2679, s.19.

[2] Bašová, S. - Štefancová, L.: Creative Parameters of Urban Spaces. In: International Journal of Arts and Commerce, Vol.5 No. 2, 2016, ISSN 1929 - 7106, www.ijac.org.uk, s. 58.

[3] Bleha, B., Šprocha, B.: Mestá a demografický vývoj In: Urbanita 1-2/2016,, ISSN 0139-5912, Vyd. MDVaRR SR, Bratislava, s.51.

[4] Bogdanovic, B.: Mesto a démoni, Vydavatel'stvo Ivan Štefánik, 2002, ISBN 80-968189-5-3, s.26.

[5] Falt’an, L'.: Bratislava - problémy súčasného rozvoja (reflexia socio-priestorových súvislostí) In: Sociológia 2009, Vol. 41 (No. 4: 329-353) ISSN 0049 - 1225, s. 330-331.

[6] Gajdoš, P., Moravanská, K.: Suburbanizácia a jej podoby na Slovensku, ISBN 978-80 85544 - 67-1, Vyd. SAV Bratislava 2011, s.6.

[7] Gehl, J.: Města pro lidi, Cities for People, Island Press2010, Partnerství Brno 2012, str. 10.

[8] Halík, P.,Kratochvíl, P.,Nový, O.: Architektura a město, Academia Praha, ISBN 80-200-02456, 1996, s.76.

[9] Hrůza, J.: Stavitelé měst, Vyd. Agora, Praha, 2011, ISBN 978-80-86820-08-8, s. 175-7.

[10] Rehák, Š.: Kreatívna trieda a kreatívne mestá. Teoretický koncept a jeho limity, In: Sociológia 46, 2014/ 5.

[11] Shrinking Cities - Volume 1-2: International Research, Edited by Philipp Oswalt, Texts by Regina Bittner, Robert Fishman, Dave Haslam, Wolfgang Kil, Walter Prigge, Klaus Ronneberger, Barbara Steiner, Thomas J. Sugrue u.a., Kulturstiftung des Bundes. Berlin, 2005-2006, ISBN 978-3-7757-1682-6, s.10.

[12] Sopirová, A.: Sídla v zázemí miest, In: ALFA STU 3/2014, ISSN 1135-2679, s.54

[13] www.wikipedia.org/wiki/European_Capital_of_Culture 